Abdrazakova Leilal Abzhaparova Laura

Master of Human Sciences Ablai Khan KazUIRandWL, Almaty, Kazakhstan,e-mail: leyla_abdrazakova@mail.ru

Doctor Phd Ablai Khan KazUIRandWL, Almaty, Kazakhstan, e-mail: laura_zh83@mail.ru

\title{
YOUTH POLICY AS A WAY IN PREVENTING SOCIAL RISKS
}

\section{Abstract}

The article gives an analysis of one of the modern forms of international youth activities, which are significant mechanism in the formation of a positive image of the country in the youth environment which is based on the experience of foreign countries. Authors refer to the history of appearance term "international youth diplomacy". The attempt to describe role of youth diplomacy in organized youth environment, identified some problematic aspects, as well as basic its development vectors within the framework of organizations and youth institutions.

Keywords: youth policy, image of the country, public diplomacy, international youth diplomacy, external cultural politics, international youth organizations, international humanitarian cooperation, international activity youth, international youth environment.

\author{
Абдразакова Лейла ${ }^{1}$ Абжапарова Лаура ${ }^{2}$ \\ ${ }^{1}$ Абылай хан атындавы өнер шебері, ҚазХҚюӘТУ, \\ Алматы, Қазақстан, Электрондық nошта: leyla_abdrazakova@mail.ru \\ ${ }^{2}$ Абылай хан атындавы ҚазХҚжӘТУ PhD докторы, \\ Алматы, Қазақ̆стан, Электрондық пошта: laura_zh83@таil.ru
}

\section{ЖАСТАР САЯСАТЫ ӘЛЕУМЕТТІК ТӘУЕКЕЛДЕРДІН АЛДЫН АЛУ ӘДІСІ}

\section{Ан̆датnа}

Мақалада шетелдік жастар тәжірибесінің негізінде жастар ортасында елдің оң имиджін қалыптастырудың маңызды тетігі болып табылатын халықаралық жастар іс-әрекетінің қазіргі заманғы формаларының біріне талдау берілген. Авторлар «халықаралық жастар дипломатиясы» терминінің тарихына сілтеме жасайды. Ұйымдастырылған жастар ортасында жастар дипломатиясының рөлін сипаттау әрекеті кейбір проблемалық аспектілерді, сонымен қатар ұйымдар мен жастар институттарындағы негізгі даму бағыттарын анықтады.

Түйінді сөздер: жастар саясаты, ел имиджі, қоғамдық дипломатия, халықаралық жастар дипломатиясы, сыртқы мәдени саясат, халықаралық жастар ұйымдары, халықаралық гуманитарлық ынтымақтастық, халықаралық жастар, халықаралық жастар ортасы. 


\author{
${ }^{1}$ Магистр гуманитарных наук Абылай-хан KazUIRandWL, \\ Алматы, Казахстан, электронная почта: leyla_abdrazakova@mail.ru \\ ${ }^{1}$ Доктор PhD Ablai Khan KazUIRandWL, \\ Алматы, Казахстан, электронная почта: laura_zh83@таil.ru
}

\title{
МОЛОДЕЖНАЯ ПОЛИТИКА КАК СПОСОБ ПРЕДОТВРАЩЕНИЯ СОЦИАЛЬНЫХ РИСКОВ
}

\begin{abstract}
Аннотация
В статье дается анализ одной из современных форм международной молодежной деятельности, которые являются важным механизмом формирования позитивного имиджа страны в молодежной среде на основе опыта зарубежных стран. Авторы ссылаются на историю появления термина “международная молодежная дипломатия". Попытка описать роль молодежной дипломатии в организованной молодежной среде, выявила некоторые проблемные аспекты, а также основные ее векторы развития в рамках организаций и молодежных институтов.

Ключевые слова: молодежная политика, имидж страны, общественная дипломатия, международная молодежная дипломатия, внешняя культурная политика, международные молодежные организации, международное гуманитарное сотрудничество, молодежь международной деятельности, международная молодежная среда.
\end{abstract}

World communities, since the 1950s and 1960s, have been pursuing a purposeful policy towards the younger generation. A special role in this process belongs to the United Nations. In 1965, the UN General Assembly adopted a "Declaration on the dissemination among youth of the ideals of peace, mutual respect and mutual understanding among peoples". In subsequent years, a number of important documents were adopted: in 1985, declared the International Year of Youth, the "Guidelines for the Further Planning and Implementation of Relevant Follow-up on Youth: Participation, Development, Peace" were endorsed; in accordance with the UN General Assembly Resolution of 14 December 1995, the World Program of Action for Youth was adopted, until the year 2000 and beyond; Resolution 54/120 of 20.01.2000 approved the Lisbon Declaration on Youth Policy and Programs, adopted in August 1998 at the first World Conference of Ministers responsible for Youth[1, p.36].

Currently, the concept of "youth"used in foreign countries is determined on the basis of different components and approaches, not only the age range, but also the characteristics (resource or problem). Modern age boundaries of the concept of "youth", adopted in most European countries, the United States and Japan, lie in the range from 13-14 to 29-30 years. At the same time, different countries use different concepts: in Great Britain and the Netherlands, young people are not allocated to a special group, but are united with children in the age range of 0-25 years. This approach has both a positive and a negative side. On the one hand, close interaction of children's and youth policy is ensured, on the other hand there is the possibility of uneven distribution of efforts between these spheres. In Spain, young people are defined as 14-30 years old, often the border is shifted to 32-34 years. This fact is explained by the fact that it is at this age that young Spaniards begin to lead an independent economically independent life. In Luxembourg, the boundaries of 15-25 years are set to determine the youth age.

In the opinion of I.M.Ilyinsky [2, p.63], it is time to talk about a fundamentally new discovery of young people, the main thing in which is to establish a point of view on youth, at least as an age that is not reducibleto age characteristics and deviations from the norm (non-maturity, non-reasonableness, etc.), but on the contrary, as the most valuable period for the present society of a person's life, in which he more than ever. It is open to the new, not obsessed with the old, actively striving for self-affirmation and selfrealization. Youth is the life force of society, a clot of energy, unspent intellectual and physical forces that require withdrawal. In his youth, the person is most capable of creative activity, the formulation of heuristic approaches arethe most workable.

In European countries, there is a diversity of concepts of youth policy. In a number of European countries, youth policy is an independent part of state policy with a clear structure and close interaction of components. In other cases, the subject for discussion is in the making. But at the same time, it is possible to identify the main elements that characterize youth policy as [3, p.45]:

- Area of distribution (geographical and social groups);

- Opportunities (role and interaction of government and youth NGOs);

- Competence (the issue of training and qualification); 
- Cooperation, management and structure (vertical and horizontal);

- Resource provision (financial and human resources).

In most European countries, youth policy is designed to help young people in the development of their life path, including in the provision of employment and civic participation of young people. The exception is Sweden, where the main task of youth policy is to help young people be young people. It is also obvious that in recent years the structure and scope of the youth policy has expanded enormously.

At the moment, we can talk about the existence of youth legislation in most European countries, although the question of integrated youth policy is still under discussion and, often, youth legislation is limited to the area of youth work and formal education.For example, Sweden is on the verge of adopting the Bill on a new youth policy, in 1997 the Youth Work Act was adopted in Finland, in the 1990s, a number of normative and legal acts were adopted in Estonia and Finland with regard to youth.

International experience shows that youth policy, as well as its legal basis - youth legislation, needs an ideological approach. In this respect, the experience of Estonia (giving great importance to education) and Finland (youth work and civic participation are priority areas of youth policy) is successful [3, p.66].

In Spain, the vertical structure is a rather complex and difficult system for initiating and implementing youth policy. But at the same time, at the local level, there is insufficient awareness of the ongoing regional youth programs. In Romania, on the contrary, there are no effective vertical structures, and the main work is entrusted to youth NGOs, which unite a small part of the Romanian youth[3, p.79].

In this regard, today it is important to understand the specific role and influence of various social institutions and groups in the formation of the image. The most significant in this regard are the role and potential, including modern youth. In particular, the multidimensional international activity of modern youth has become an increasingly important place among the positive factors that have a certain influence on the formation of the country's image. It is no accident that such youth activities, formulated in contemporary literature as international youth cooperation, youth relations, characterize the main forms of its institutional interaction on the international arena. In addition, in the international environment, the most important form of youth activity is elements of traditional diplomacy aimed at building peer relations through the means of public organizations, culture, science, sports, etc.

An analysis of materials on the state of the international youth movement in the late 1980s. XX century. makes it possible to note that the participation of young people in the people's diplomacy and the creation of their own "youth diplomacy" were viewed as one of the most urgent tasks in the international activities of various associations of the younger generation. However, the wide practical application of this term occurred much later. In particular, in recent decades, the term "youth diplomacy", especially in relation to its international activities, has not only become increasingly used in the publications of domestic media, but has also become a sought-after instrument aimed at activating the institutional role of youth in the international environment. Meanwhile, it seems possible to consider youth diplomacy as a set of forms, means and methods of conducting international youth activities[4, p.12].

Inadequate theoretical and practical study of one of the modern forms of international youth activity - youth diplomacy - requires considering and taking into account not only many factors that directly affect its character and development, but also an understanding of its role and influence on the formation of a positive image of the country in the youth environment.

In the context of the foregoing, the problems and perspectives of the still fragile, still emerging model of international youth interaction - "international youth diplomacy" as a form of people's diplomacy, which have recently been more often considered public or public diplomacy, deserve special attention in the context of the foregoing. Public diplomacy in Russia (the translation of the American term "public diplomacy") considers the building of international relations not only on a political level, but also by means of culture, science, business and public organizations. Unlike official diplomacy, which is primarily the prerogative of states, public diplomacy attracts with its openness, the possibility of broad participation in it of public institutions[4, p.14].

In the context of the foregoing, it can be noted that the ideas of public diplomacy among young professionals in the field of international relations, diplomacy, history and journalism are becoming more popular, advocating the strengthening of humanitarian cooperation and public communication between Russia and foreign countries, including youth line. The need for mechanisms for communication and exchange of opinions among young experts was dictated by the creation in 2010 of a non-profit organization "Center for Support and Development of Public Initiatives Creative Diplomacy"to develop and support civic initiatives aimed at creating an atmosphere of positive perception of Russia's image in public. and media space abroad through the development of public diplomacy[5, p.68]. 
However, despite the fact that youth diplomacy today is an objective necessity, it is not always used as a resource aimed at shaping the country's image. No one was deliberately engaged in shaping the image of Russia abroad with the help of public youth organizations. Today, existing specialized youth organizations that develop international youth cooperation still lack the organizational and resource potential for active participation in public diplomacy events.

Today, there is a need to form a fundamentally new system of international propaganda for the positive image of Russia. To this end, the youth environment is seen as an important field for the purposes of our country. As noted by the political scientist A.Shatilov, international youth events have not lost their relevance, with their help it is possible to save future generations from negative stereotypes. As examples, Germany is considered, which, in the opinion of the political scientist, largely corrects its negative image after the Second World War through the youth exchange with countries with which it used to fought12. Other ideas aimed at forming a positive image of Russia are suggested. As such events are hold in 2017 the International Festival of Youth and Students, like those in 1957 and 1985. passed in the USSR, an increase in the number of Russian centers of science and culture, work with compatriots and foreign youth [5, p.69].

The League of International Youth Diplomacy is an independent public organization, the main office is located in St. Petersburg, but there are representatives and partners in other regions of Russia and the world: Moscow, Siberia, the Far East, Paris, Berlin, Milan, in Rome, London, New York, Washington, Vancouver, Toronto, Tokyo, Ankara, Baku. The main activity is to promote cooperation between young leaders and their organizations at the international level through international public projects. The League helps identify young leaders in politics, business, civil society, world politics and economy, young leaders in the spheres of culture and sports of different countries[6, p.10].

The project "Public Diplomatic Corps" is included in the Action Plan for 2014-2015. The Framework Program for Cooperation between the Russian Federation and the Council of Europe in the Sphere of Youth Policy for 2014-2018. The project is being implemented in close cooperation with the Ministry of Foreign Affairs of the Russian Federation, and the Public Chamber of the Russian Federation. The mission of the project is to unite the team of youth leaders who are not only willing, but also doing, whose task is to promote the development of international humanitarian cooperation, to represent the interests, culture and traditions of countries at the international level by participating in various programs and projects of youth themes, implementing joint activities on development and popularization in society and youth of the principles and best traditions of democracy, parliamentarism, civic engagement, mutual respect, goodwill intercultural dialogue, solidarity, based on international experience.

In addition, active involvement of young people in the process of forming a positive perception of their country in the international youth environment requires participants to have certain skills and level of preparation. In this regard, the participation of a small part of the country's youth in this process indicates the lack of a specific program of youth action in the international environment at the federal level. Taking into account these and other aspects of youth diplomacy in the context of forming the image of the country, it became necessary to expand the field of international youth activities with the participation of youth organizations and institutions.

In conclusion, youth diplomacy can be viewed as an additional tool aimed at creating a positive image of countries, which is formed not only in the framework of an exchange of views, dialogue among young people, but also with concrete actions of its participants.Despite the fact that the variety of forms of institutional youth activities in the international environment and its impact on the image of the country is beyond the scope of research interest, today its further study can more likely open new horizons of discourse regarding the youth factor's perspective with the aim of implementing an effective external cultural policy country as a whole. The prospects for this policy will depend not only on the high level of the role and significance of multifaceted international youth activities, but also on the purposeful constructive approach aimed at developing this direction.

References:

1. Beever, E. and Green, E. (2017) Unpublished Summary Report: The impact of leaving the EU on the youth work sector. Edinburgh, YouthLink. - P.300 
2. Ильинский И. М. Молодежь и молодежная политика. Философия. История. Теория. М.: Голос, 2013. - 696 c.

3. Coburn, A. and Gormally, S. (2017) Communities for Social Change: Practising Equality and Social Justice in Youth and Community Work. New York, Peter Lang. - P. 153

4. Меркулов П.А. Реализаиия государственной молодёжной политики в регионах РФ// Власть. - 2015. - № 9. - С. 12-15

5. Coburn A. (2016) Building social and cultural capital through learning about equality in youth work. Journal of Youth Studies (14) (4). pp.475-499.

6. McCulloch, K.\& Shaw, M. (2015) 'Hooligans or rebels? Thinking more critically about citizenship andyoung people’ Youth \& Policy, No.101, pp. 5-14. 